\title{
Konsep “Mecaru” Dalam Budaya Bali Sebagai Jembatan Penginjilan Terhadap Orang Bali
}

\author{
Ni Nyoman Fransiska M.Th \\ Fransiska.nyoman@yahoo.com
}

\section{A. PENDAHULUAN}

Bali adalah nama salah satu provinsi di Indonesia yang memiliki banyak keunikkan, baik karena alam maupun kebudayaannya. Bali adalah satu-satunya pulau di Indonesia yang mayoritas penduduknya beragama Hindu. Hal ini terjadi setelah jatuhnya Kerajaan Majapahit yang semula adalah Kerajaan Hindu ke tangan Kerajaan Islam. Masyarakat Bali terbentuk dari penyatuan berbagai macam perbedaan, mulai dari perbedaan suku, ras, kebudayaan, kepercayaan, dan lainnya. Salah satu perbedaannya yaitu kepercayaan (Agama). Keanekaragaman agama dan kebudayaan di Indonesia khususnya Bali tidak lepas dari pengaruh kedatangan bangsa barat ke Indonesia yang dapat dilihat dari pengaruh kebijakan kolonial yang ada pada zaman kolonial. Bali yang identik dengan Pura Seribu Pura dengan, susunan masyarakat serta kepercayaan asli Bali, tidak menutup kemungkinan untuk masuknya agama lain. Namun, selain Agama Hindu sebagai agama mayoritas terdapat juga penganut agama lain seperti Agama Islam, Kristen dan Budha lengkap dengan tempat beribadah masing-masing tersebut. Salah satu Agama yang akan dibahas dari latar belakang ini yaitu agama Kristen baik Kristen Protestan atau Katolik. Banyak kajian ilmiah yang telah ditulis oleh para peneliti, yang hanya memposisikan Bali sebagai masyarakat yang beragama Hindu, padahal secara empirik dalam masyarakat Bali terdapat komunitas-komunitas keagamaan lain seperti Kristen, Islam, Budha serta aliran-aliran kepercayaan lain. Agama Kristen merupakan Agama yang tersebar hampir di seluruh kabupaten di Bali, yaitu Kabupaten Badung, Tabanan, Bangli, Buleleng, Karangasem, Gianyar, Jembrana, Klungkung, dan Denpasar. 


\section{Latar Belakang Mecaru}

Sebagai umat manusia yang merupakan ciptaan Tuhan Yang Maha Esa, Ida Sang Hyang Widhi Wasa, maka diharapkan dan harus mempunyai suatu sikap hormat dan menghargai atas kekuasaan dan kebesaran-Nya dan atas segala ciptaan-Nya. Maka dari itu, tiada kata lain dalam perwujudan bhakti dan hormat kita adalah dengan melakukan Yadnya. Yadnya bila dilihat dari tindakan dapat dibagi dua bagian, yaitu Yadnya yang dilakukan secara riil (nyata) dan abstrak (tidak nyata). Yang nyata dapat berupa persembahan dan atau korban suci kehadapan Hyang Widhi demikian juga kehadapan sesama makhluk hidup, sedangkan secara tidak nyata dapat berupa Tapa, Bratha, Yoga, dan Semadhi.

Berbicara masalah Yadnya yang nyata yaitu persembahan dan korban suci, secara riil telah diketahui bersama yakni Panca Yadnya. Panca yadnya memiliki lima bagian yakni Dewa Yadnya (persembahan kepada Tuhan), Pitra Yadnya (persembahan kepada leluhur), Manusia yadnya (persembahan kepada sesama manusia), rsi Yadnya (persembahan kepada para rsi), dan Bhuta Yadnya (persembahan kepada para bhuta kala).

Dalam Bhuta Yadnya, terkait dengan upacara tersebut disebut dengan Mecaru. Upacara tersebut dilakukan oleh umat setiap saat baik di peresmian rumah, banjar, desa, pura dan bahkan suatu wilayah. Demikian juga setiap harinya, hari-hari tertentu seperti kajeng kliwon, dan atau pada pergantian sasih secara rutin upacara mecaru ini dilaksanakan. Disamping itu upacara mecaru ini diselenggarakan juga pada setiap adanya suatu peristiwa kejanggalan dan atau kejadian yang tiada kita hendaki.

Upacara Mecaru di Bali atau juga disebut dengan Butha Yadnya merupakan sebuah ritual suci yang kerap digelar untuk mengharmonisasi hubungan antara manusia dengan lingkungan sekitarnya. Manusia dengan alam, memang sejatinya tidak boleh saling bertentangan satu dengan yang lainnya supaya tercipta saling pengertian dan hubungan yang kondusif untuk keberlangsungan kehidupan selanjutnya. 
Upacara-upacara tersebut secara rutin masih dilakukan oleh umat Hindu dipedesaan. Namun apa sesungguhnya upacara dimaksud dan apa tujuannya ternyata banyak dikalangan umat Hindu yang tidak tahu secara Tattwa. Kalau ditanya ya jawabnya “mule keto". Hal ini tidak tidak boleh dibiarkan terus. Lebih-lebih dalam memasuki era globalisasi. Oleh karena itu upacara-upacara tersebut diatas perlu diungkapkan secara ilmiah popular untuk mudah dipahami terutama oleh umat Hindu sendiri, bila hal ini kita tidak lakukan akan timbul kekhawatiran nantinya tentang kelanjutan pelaksanaan upacara dimaksud.

\section{Pengertian Caru}

Caru adalah kurban suci yaitu upacara yadnya yang bertujuan untuk keseimbangan para bhuta sebagai kekuatan bhuwana alit maupun bhuwana agung sebagaimana disebutkan dalam kanda pat butha sehingga dengan adanya keseimbangan tersebut berguna bagi kehidupan ini.

Dalam kitab Samhita Swara disebutkan, arti kata caru adalah cantik atau harmonis. Upacara Butha Yadnya itu disebut caru karena disebabkan salah satu tujuan Butha Yadnya adalah untuk mengharmoniskan hubungan manusia dengan alam lingkunganya. Caru yang dalam sejarahnya disebutkan diawali dari terjadinya kekacauan alam semesta yang mengganggu ketentraman hidup sebagai akibat dari godaan-godaan bhuta kala, sehingga Hyang Widhi Wasa menurunkan Hyang Tri Murti untuk membantu manusia agar bisa menetralisir dan selamat dari godaangodaan para bhuta kala itu sehingga mulailah timbul banten "Caru" sebagaimana disebutkan dalam mitologi caru ini.

Dan dijelaskan pula bahwa, Caru (Mecaru; Pecaruan; Tawur) sebagai upacara yadnya yang bertujuan untuk keharmonisan bhuwana agung (alam semesta) dan bhuwana alit agar menjadi baik, indah, lestari sebagai bagian dari upacara Butha Yadnya,

Dengan demikian, upacara mecaru adalah aplikasi dari filosofi Tri Hita Karana. Yakni agar terjadi keharmonisan dalam hubungan antara manusia dengan Sang 
Hyang Widhi (Parahyangan), hubungan antara manusia dengan sesama manusia (Pawongan)dan hubungan antara manusia dengan alam (Palemahan).

\section{Maksud dan Tujuan Caru}

Upacara Mecaru ini berfungsi untuk menanamkan nilai-nilai luhur dan spiritual kepada umat manusia agar selalu menjaga keharmonisan alam, lingkungan beserta isinya (wawasan semesta alam). Sementara makna upacara mecaru sendiri adalah kewajiban manusia merawat alam yang diumpamakan badan raga Tuhan dalam perwujudan alam semesta beserta isinya. Serta untuk memohon kehadapan Ida Sang Hyang widhi Wasa agar senantiasa kehidupan kita sebagai umat manusia cipaanNya mendapatkan kehidupan yang baik dan sejahtera secara sekala dan niskala.

Lain daripada itu, segala ketidakharmonisan yang terjadi di alam semesta ini juga disebabkan oleh perilaku manusia itu sendiri, seperti halnya memelihara bumi yang tiada semestinya dan juga pengingkaran akan ajaran agama, dharma, dan kesucian. Hal iu yang menyebabkan suatu keadaan buruk di jagat raya ini. Semuanya itu patut diberikan Caru agar mendapatkan keharmonisan kembali serta mendapatkan kerahayuan dengan terbatasnya dari segala bentuk kekotoran (leteh) dan kembali dikasihi oleh tuhan Yang Maha Esa, Ida Sang Hyang widhi Wasa.

Begitu banyaknya Tuhan Yang Maha Esa memberikan kemudahan bagi umat manusia agar dipergunakan sebagai mana mestinya, namun dari semua itu juga Hyang Widhi (Tuhan Yang Maha Esa) menitipkan alam beserta ini agar tidak dirusak dan selalu dijaga untuk kelangsungan kehidupan manusia. Alam dan manusia, sampai kapanpun harus selalu bersatu karena diantara keduanya saling membutuhkan satu dengan yang lainnya.

\section{a. Dengan Caru Mengatasi Bhutakala}

Bhuta Kala umumnya dibayangkan sebagai suatu makhluk ajaib yang berwajah serem menakutkan. Mulutnya lebar, bertaring panjang, mata merah mendelik, rambut tergerai tanpa aturan, perut gendut dengan sikap garang. Keadaan itu sering diwujudkan dengan ogoh-ogoh menjelang Nyepi. Penggambaran Bhuta Kala itu sangatlah wajar sebagai imajinasi para seniman dan rohaniawan. Karena kalau manusia. tidak harmonis dengan Bhuta Kala perasaan ngeri seperti melihat 
Bhuta Kala yang digambarkan di atas. Dalam bahasa sehari-hari di kalangan umat Hindu terutama di Bali ada istilah mecaru untuk nyomia Bhuta Kala. Upacara nyomia Bhuta Kala artinya mengubah sifat ganas Bhuta Kala menjadi bersifat lembut membantu manusia untuk mengembangkan perbuatan baik.

Jadi hakekat upacara mecaru itu adalah memotivasi spiritual agar selalu berbuat mengubah sifat ganas menjadi lembut tentang keberadaan Bhuta Kala itu. Dengan demikian terjadilah suatu hubungan yang harrnonis antara manusia dengan Bhuta Kala, Keharmonisan itulah tujuan dari upacara mecaru itu.

Bhuta Kala yang digambarkan itu tidak lain dari pada sifat-sifat alam kita ini. Manusia hidup bersama alam bahkan jasmani manusia juga disebut alam kecil atau Bhuwana Alit. Sifat alam kadang-kadang sebagai sahabat manusia kadang-kadang sebagai musuh manusia. Api dan air bisa menjadi sahabat dan membantu kehidupan manusia. Bisa juga menjadi musuh manusia seperti menimbulkan kebakaran, banjir dan lainnya. Agar alam itu selalu dapat bersahabat dengan manusia, yang harus aktif membangun persahabatan itu adalah manusia itu sendiri. Persahabatan dengan alam itu dapat dilakukan dengan cara sekala atau nyata dan dengan cara niskala atau dengan cara kerokhanian. Upacara mecaru adalah membangun persahabatan dengan alam dengan cara niskala. Cara niskala ini harus seimbang dengan cara sekala. Dengan demikian Bhuta Kala itu akan selalu menjadi sahabat membantu kehidupan manusia.

\section{b. Persembahan Kepada Panca Maha Bhuta}

Banten Caru yang golongannya lebih kecil disebut dengan Segehan, dipersembahkan kehadapan Ida Sang Hyang Widhi Wasa dalam prabawanya sebagai Panca Maha Bhuta. Disebutkan juga bahwa, manusia sebagai ciptan-Nya merupakan perwujudan Panca Maha Bhuta dalam bentuk kecil atau mikrokosmos, sedankan alam yang lebih besar makrokosmos adalah alam semesta ini.

Alam semesta ini terbagi menjadi beberapa lapisan menurut keagamaan, yang paling sering dan paling diketahui bersama adalah adanya alam Bhur, Bwah, Swah. Alam Bhur adalah tempat manusia disamping pula oleh segala gumatat-gumitit, para bhutakala, dedemit dan makhluk lainnya. Alam Bwah adalah alam para arwah. 
Sedangkan alam Swah adalah adalah alamnya para Dewa. Sedangkan Panca Maha Bhuta di dalam diri manusia terdiri dari tiga lapis yakni Stula Sarira (badan kasar), Suksma Sarira (badan halus), dan Antahkarana Sarira (atman) dan ketiganya disebut sebagai Tri Sarira.

Melihat kenyataan bahwa alam Bhur tidak hanya dihuni oleh manusia dan dengan makhluk hidup lainnya saja, akan tetapi dihuni pula oleh para makhluk halus lainnya, maka sudah jelas akan adanya suatu interaksi dengan yang lainnya yang akan menimbulkan gesekan dan pengaruh diantaranya. Untuk itulah dalam kaitan menetralisir dan mengharmoniskannya diadakan suatu persembahan berupa 'Caru' yang golongannya lebih kecil yang disebut segehan. 'Mesegeh'(dalam bahasa bali) dilakukan pada setiap hari Kajeng, Kliwon, dan Kajeng Kliwon serta juga pada saat rerahinan lainnya.

\section{Jenis- Jenis Caru dan Pelaksanaannya}

Lontar Dewa Tattwa membedakan jenis-jenis Caru dan Tawur sebagai berikut:

1. Yang diadakan bila ada kejadian tertentu misalnya: bencana, bencana alam, hama penyakit, gerhana matahari, huru-hara, perang, dll.

2. Yang diadakan: sehari-hari, hari tertentu, sasih (bulan) tertentu, dan warsa (tahun) tertentu.

3. Yang diadakan disuatu tempat: pekarangan, rumah, pura, sanggah, Banjar, Desa Adat, seluruh pulau (Bali), seluruh dunia, danau, laut, hutan, gunung, dll.

4. Mengikuti upacara pokok Panca Yadnya.

\section{Sarana Upakara dalam Pecaruan}

Sarana yang dimaksud dalam uraian ini adalah sarana atau perlengkapan dan atau bagian dari Caru tersebut. Hal ini dapat berupa nasi, tumbuhan, binatang, dan unsur alam lainnya. Hal ini disesuaikan dengan jenis daripada caru tersebut. Caru dalam arti sempit dan sederhana sarananya dapat berupa nasi dengan berbagai bentuknya seperti, nasi kepelan, nasi cacahan, tumpeng yang dilengkapi dengan lauk pauk, bawang jahe, garam, demikian juga dengan Caru yang tergolong lebih besar dapat 
disertai dengan daging jeroan olahan dan bahkan kepala dari suatu bunatang yang dipakai korban yang kesemuanya berbau amis dan serta dibarengi dengan minuman yang beralkohol seperi tuak.arak berem disamping juga air tentunya. Bilamana sarananya berupa tumbuhan dapat dilihat dari digunakannya salah satunya adalah daun kelapa yang berupa Sengkui yang dibuat sedemikian rupa dan disesuaikan dengan urip dari suatu arah mata angin.

Menurut Lontar Sudamala, bahan-bahan upakara dalam pecaruan terdiri dari tiga jenis:

1. Mataya; bahan dari tumbuh-tumbuhan: daun, bunga, buah, pohon, bijibijian, umbi-umbian, arak berem, tuak.

2. Mantiga; hewan yang lahir dua kali (melalui telur): ayam, bebek, angsa, burung.

3. Maharya; hewan yang lahir satu kali (tidak melalui telur) dan berkaki empat: babi, sapi, kerbau, kambing, anjing.

Penempatan warna bulu hewan caru mengacu pada kedudukan Panca Korsika dan Bhuta, disesuaikan dengan warna bulu hewan itu. Hal ini juga disebutkan dalam ephos Mahabharata, ketika Dewi Kunti hendak mengorbankan Sahadewa untuk "nyupat" Panca Korsika.

Makna simbol warna dalam Upacara Pecaruan (Lontar Dewa Tattwa)

seperti warna-warna bulu hewan, kober, tumpeng, kelungah, dangsil, sanganan, nasi, beras, bunga, benang, dll mengikuti warna pengider:

1. Sweta (putih),

2. Dumbra (merah muda),

3. Rakta (merah),

4. Rajata (oranye),

5. Pita (kuning),

6. Syama (hijau),

7. Kresna (hitam), 
8. Biru (abu-abu),

9. dan sarwa suwarna (campuran)

Warna-warna itu selain sebagai identitas para dewa yang menjaga keseimbangan, juga sebagai simbol berbagai sifat yang ada dalam diri manusia:

1. Putih: suci;

2. Merah-muda: kesucian yang ternoda oleh kemarahan;

3. Merah : marah;

4. Oranye: marah karena nafsu tak terpenuhi;

5. Kuning: nafsu;

6. Hijau: serakah;

7. Hitam: iri-hati;

8. Abu-abu: iri-hati yang terselubung.

Dari 9 warna yang ada, hanya 1 (warna putih) sebagai simbol sifat baik yang bisa dikalahkan oleh warna lain simbul keburukan. Oleh karena itu warna putih dibanyakkan dengan tepung beras yang dirajah pada banten Rsi Gana. Dengan demikian sifat-sifat buruk asubha karma manusia diusahakan di-"somiya" melalui pecaruan sehingga Asuri Sampad (sifat keraksasaan) dapat berubah menjadi Daiwi Sampad (sifat kedewataan)

\section{Caru Menggunakan Binatang}

Banten Bhuta Yadnya yang disebut caru selalu menggunakan binatang kurban. Penggunaan binatang ini sangat menentukan nama dan tingkatan banten caru tersebut. Misalnya caru Eka Sata menggunakan ayam brumbun atau lima warna. Caru Panca Sata menggunakan lima ekor ayam.

Demikian seterusnya, pemakaian binatang dan tumbuh-tumbuhan sebagai sarana upacara Yadnya telah disebutkan dalam Manawa Dharmasastra V.40. Tumbuhtumbuhan dan binatang yang digunakan sebagai sarana upacara Yadnya itu akan meningkat kualitasnya dalam penjelmaan berikutnya. Manusia yang memberikan 
kesempatan kepada tumbuh-tumbuhan dan hewan tersebut juga akan mendapatkan pahala yang utama. Karena setiap perbuatan yang membuat orang lain termasuk sarwa prani meningkat kualitasnya adalah perbuatan yang sangat mulia. Perbuatan itu akan membawa orang melangkah semakin dekat dengan Tuhan. Karena itu penggunaan binatang sebagai sarana pokok upacara banten caru bertujuan untuk meningkatkan sifat-sifat kebinatangan atau keraksasaan menuju sifat-sifat kemanusiaan terus meningkat menuju ke sifat-sifat kedewaan.

\section{Nitya dan Naimitika Karma}

Bila dilihat dari pengertian, maka caru terdiri dari berbagai macam sesuai dengan jenis/wujud, sarana dan peruntukan serta tujuannya. Untuk hal itu akan dijelaskan bahwa upacara Yadnya, khususnya Bhuta Yadnya dalam hal ini dapat dilakukan dengan dua fase, yaitu secara keseharian atau tiap hari yang disebut dengan Nitya Karma dan setiap waktu tertentu disebut dengan Naitmitika Karma.

Nitya Karma adalah suatu persembahan korban suci kehadapan Dewa dan Bhutakala yang dilakukan setiap hari setelah memasak nasi dengan beberapa butir nasi beralaskan daun pisang persegi yang dilengkapi denga lauk pauk yang dimasak saat itu dan dihaturkan pada pelinggih di Mrajan/Sanggah khususnya diletakkan pada bebaturannya, selanjutnya dihaturkan kepada para makhluk halus yang berkeliaran siang dan malam (bhutakala) yang senantiasa mengganggu ketentraman. Jadi hakekatnya yadnya sesa tersebut ditujukan kehadapan para dewa dan bhuta (unsur pertiwi, apah, teja, bayu, dan akasa) serta bhutakala (makhluk halus yang berkeliaran). Disamping itu secara etika, yadnya sesa atau mebanten saiban sebenarnya megandung unsur mendidik, bahwa kita sebagai umat senantiasa wajib untuk mensyukuri atas rahmat yang diberikan oleh sang Pencipta, selalu mendahulukan dan serta wajib melakukan punia kehadapan sesama makhluk ciptaan-Nya.

Sedangkan Naimitika Karma adalah suatu persembahan korban suci yang diadakan setiap saat bilamana diperlukan. Persembahan ini wujudnya merupakan upacara Mecaru. Mengenai caru ini ada berbagai jenis dan wujudnya sesuai dengan peruntukkan serta tujuannya. Secara umum caru atau Mecaru adalah untuk menjaga keharmonisan alam semesta beserta isinya sebagai aibat perilaku daripada para 
Bhutakala yag dengan sengaja mempengaruhi dan atau berbuat jahat terhadap manusia seingga terjadi ketidak nyamanan, ketidak tentraman dan serta ketidak harmosisan dari alam beserta isinya. Selanjutnya setelah diberikan persembahan korabn suci, para Bhuta senantiasa tidak kembali melakukan gangguan serta seantiasa menjaga ketentraman, kedamaian, serta keharmonisan jagat raya beserta isinya.

\section{B. MECARU SEBAGAI SARANA PENGINJILAN}

Korban adalah sarana umat untuk lebih mendekatkan diri kepada Allah bukan karena umat bermasud minta balasan berdasarkan korban yang sudah diberikan, melainkan korban itu adalah korban sukarela kepada Allah juga sebagai tebusan atas pelanggaran umat kepada Allah Menurut Imamat 7:37, ada lima korban yang termasuk dalam hukum dinyatakan Tuhan Allah kepada Musa di Gunung Sinai dan memerintahkan orang Israel mempersembahkan persembahan mereka di padang gurun Sinai. Kelima macam korban itu adalah korban bakaran, korban sajian, korban penghapus dosa, korban penebus salah dan korban keselamatan. Kelima macam korban tersebut mempunyai tujuan yang berbeda tetapi pada intinya sama yaitu sebagai pendamaian dan ucapan syukur. Dimana tindakan pendamaian di dalam kata ini berhubungan dengan sistim persembahan untuk menyelesaikan masalah dosa atau pelanggaran.

\section{Yesus Kristus adalah Korban/Caru Agung}

"Dalam Perjanjian Baru kurban berupa kambing dan domba dianggap lambang saja, "sebab tidak mungkin darah lembu jantan atau darah domba jantan menghapuskan dosa (Ibr. 10:4). Sedangkan, darah Kristus yang dipersembahkan sekali untuk selama-lamanya merupakan kurban yang sempurna." 1 Korban yang layak menggantikan kita di hadapan Allah haruslah lebih tinggi dari seekor hewan. Karena tidak mungkin darah domba jantan menghapuskan dosa (Ibrani 10:4), maka korban yang dapat diterima Allah hanyalah korban seorang manusia. Dan haruslah manusia yang suci,

\footnotetext{
${ }^{1}$ Lasor, W.S dkk, Pengantar Perjanjian Lama 1, ( Jakarta: BPK.Gunung Mulia, 2001), hal.220
} 
tanpa dosa, dan diutus oleh Allah. Didalam Alkitab tidak ada yang mengatakan Yesus berdosa. Sebaliknya banyak ayat Alkitab yang menyatakan bahwa Yesus tidak berdosa sama sekali. Ibrani 4:15 menulis, "Imam Besar (Yesus) yang kita punya tidak berbuat dosa." Dengan demikian Yesus Kristus adalah satu-satunya yang dapat menjadi korban yang sebenarnya. Mengapa? Karena Dia suci, datang ke dunia dengan cara yang ajaib, dan diutus oleh Allah. Seperti halnya korban yang harus terlebih dahulu hidup lama sebelum siap dikorbankan, demikian juga Yesus. Ia hidup cukup lama sebelum mengorbankan diri-Nya sebagai tebusan bagi umat manusia. Kematian-Nya di kayu salib telah membuat darah-Nya tertumpah. Dia adalah korban penebusan yang sesungguhnya, seperti yang diucapkan oleh Yohanes Pembaptis: "Lihatlah Anak Domba Allah, yang menghapus dosa dunia" (Yohanes 1:29). Kematian-Nya telah memberikan hidup kepada manusia berdosa. Dia, yang tidak mengenal dosa telah mengorbankan diri-Nya, supaya dalam Dia orang berdosa dapat diselamatkan. Pengorbanan-Nya mencakup bagi seluruh umat manusia termasuk kita semua. Jelaslah kepada kita bahwa konsep korban sebenarnya adalah gambaran dari korban yang di berikan Kristus yang menebus dosa. Yesus Kristuslah yang mendamaikan kita dengan Allah. Dia menderita dan mati sebagai korban yang tak bercacat bagi manusia yang berdosa.

\section{a. Menyelamatkan}

Allah sendiri yang memberikan jalan keluar atas dosa dan kematian, yaitu dengan sistem penggantian atau substitusi. Setelah manusia berdosa, dijalankan sistem penggantian. Setelah Adam berdosa di hadapan Allah, Allah menentukan sistem penggantian dengan darah yang dicucurkan, binatang yang mati dibunuh. Pertama binatang yang dibunuh untuk pakaian Adam dan Hawa, kemudian ada korban Habel yang diterima. Ada sistem penggantian. Tetapi sistem korban orang Israel tidak mencapai puncaknya, hanya merupakan satu simbol atau bayang-bayang yang akan datang. Kalau kita bandingkan dengan Ibrani 10:1-5, binatang tidak mungkin mengganti manusia karena ada perbedaan kualitas. Yang bisa menggantikan manusia haruslah manusia juga. Maka dikatakan, tidak ada cara lain, Allah Bapa 
menentukan Tuhan Yesus Kristus menjadi jalan pendamaian, yakni harus mati menebus dosa, harus mati untuk membayar hutang dosa dengan memakukan surat dakwaan, surat hutang itu di kayu salib (Rom. 3:25; Kol. 2:14-15). Itu cara yang Allah tentukan, dan hanya satu cara itu. Manusia bersalah kepada Allah, harus Allah yang menentukan cara pengampunan, dan cara pengampunan itu adalah melalui kematian Kristus Yesus di kayu salib - yang menggantikan. Y esus menanggung hukuman, yang seharusnya ditanggung manusia, demi menyelamatkan manusia dari nasib yang kekal, hukuman yang adil untuk dosa-dosanya. Karena kasihNya yang begitu besar untuk kita, Yesus menyerahkan nyawaNya (Yohanes 15:13), membayar hukuman yang seharusnya kita tanggung, tapi tidak sanggup kita tanggung.

Yesus kemudian dibangkitkan, menunjukkan bahwa kematian-Nya memang sudah dianggap setimpal untuk membayar hukuman dosa umat manusia (1 Korintus 15).

Yesus menyelamatkan, namun siapa yang Dia selamatkan?

Yesus menyelamatkan semua yang bersedia menerima karunia keselamatanNya. Yesus menyelamatkan semua yang percaya pada pengorbananNya sebagai pembayaran untuk dosa (Yohanes 3:16; Kisah 16:31). Yesus menyelamatkan kita karena ia mati demi kita. Dan, alangkah bernilainya persediaan yang dihasilkan oleh kematiannya itu! Jika kita melihat hal ini sebagai bagian dari solusi Allah bagi problem yang kompleks dari dosa Adam, iman kita kepada Yehuwa dan cara Ia melakukan segala sesuatu akan diperkuat. Ya, kematian Yesus merupakan sarana untuk menyelamatkan "setiap orang yang memperlihatkan iman" kepadanya sehingga tidak menjadi korban dari dosa, penyakit, usia tua, dan kematian itu sendiri. (Yohanes 3:16)

Sekalipun pengorbanan Yesus setimpal untuk membayar dosa dari seluruh umat manusia, Yesus hanya menyelamatkan mereka yang secara pribadi 
telah menerima anugerah-Nya yang paling berharga ini (Yohanes 1:12). Tuhan memberi keselamatan kepada orang percaya melalui penebusan dengan darah-Nya, setelah itu Tuhan membentuk kita melalui berbagai kesulitan, bahkan penderitaan. Tidak ada cara lain untuk mengubah umat pilihan selain dengan berbagai persoalan yang harus dihadapi. Penggarapan Tuhan ini dilakukan demi tercapainya tujuan keselamatan, yaitu mengembalikan manusia ke rancangan Allah semula. Kalau ada orang Kristen yang menolak hal ini, maka ia sama saja menolak Injil yang diberikan melalui Tuhan Yesus Kristus. Sebab Injil atau kabar baik bukan keselamatan hari ini, tetapi keselamatan kekal.

Kalau Injil ditawarkan sekadar mengentaskan seseorang dari kemiskinan dan masalah-masalah fisik, maka itu bukanlah Injil yang benar. Tentulah Yesus yang mereka kenal bukanlah Yesus yang sejati, tetapi Yesus fantasi. Ini bukan berarti Injil mengabaikan berkat jasmani. Tetapi berkat jasmani, hendaknya tidak membutakan pengertian seseorang terhadap maksud keselamatan diberikan. Bila Injil diberitakan untuk kenyamanan hidup jasmani, maka hal ini menjadi penyesatan yang akhirnya menyejajarkan Injil dengan agama lain.

\section{b. Mendamaikan}

Dalam Kitab-Kitab Ibrani, kata-kata yang berkaitan dengan pendamaian sering muncul, terutama dalam buku Imamat dan Bilangan. Ka·far' adalah kata Ibrani untuk mengadakan pendamaian, dan mungkin pada mulanya kata itu berarti "menutup", atau mungkin juga "menghapus". Dosa manusia menimbulkan perpecahan antara Allah dan manusia, sebab Yehuwa tidak berkenan atas dosa. Hubungan yang terputus antara manusia dan Penciptanya dapat dipulihkan hanya dengan memenuhi tuntutan untuk menyediakan "penutup" atau mengadakan pendamaian yang sesungguhnya bagi dosa tersebut "Upacara korban dalam Perjanjian Lama berpusat pada kata kerja bahasa Ibrani kipper yang biasanya diterjemahkan dengan "mendamaikan" atau "menutupi" (Imamat 1:4). Arti dasarnya barangkali 
"menutupi" atau "menghapuskan". Atau kata kerja ini menunjuk kepada proses penebusan atau pendamaian dengan membayarkan sejumlah uang atau upeti, yang mencerminkan arti kata benda Ibrani koper ("harga tebusan”). Berdasarkan konteks alkitabiah (terutama Imamat 17:11), arti terakhir ini paling tepat mencerminkan konsep Ibrani."2 Dari pengertian tersebut dapatlah dikatakan bahwa korban-korban yang dipersembahkan oleh Israel kepada Allah dalam Perjanjian Lama adalah merupakan pengganti (substitusi) nyawa mereka sendiri. Gagasan ini jelas terlihat dalam peristiwa korban-korban yang dicurahkan darahnya. Dalam hal ini, darah bukan unsur yang mengandung tenaga gaib, tetapi diterima Allah sebagai pengganti nyawa atau sebagai tebusan orang yang beribadah itu.

Dosa memang merusak hubungan manusia dengan Allah dan menjadikan rintangan bagi manusia untuk datang kepada Allah. Kitab Imamat memberikan gambaran bahwa untuk mengatasi rintangan yakni dengan ibadat korban. Hal ini merupakan sifat yang asasi dari Allah dalam Perjanjian Lama maupun Perjanjian Baru. Korban dalam Kitab Imamat mempunyai pembatasan sebab hanya bisa menghapus dosa yang tidak disengaja atau bahkan ini hanya bersifat ritual. Berbeda dengan konsep korban dalam perjanjian Baru.

Manusia Membutuhkan Pendamaian. Manusia membutuhkan penutupan dosa atau pendamaian karena adanya dosa warisan (1Raj 8:46; Mz 51:5; Pkh 7:20; Rm 3:23), yang harus ditanggung oleh manusia sendiri, bukan Allah. (Ul 32:4, 5) Adam, yang telah kehilangan kehidupan abadi dalam kesempurnaan manusiawi, mewariskan dosa dan kematian kepada anakanaknya (Rm 5:12); karena itu, keturunan Adam harus dihukum mati. Agar umat manusia dapat memperoleh kembali kesempatan untuk menikmati kehidupan abadi, maka, selaras dengan prinsip hukum yang belakangan Yehuwa masukkan dalam Hukum Musa, yaitu "mata ganti mata", harus diadakan pendamaian, harus ada sesuatu yang persis sama, untuk menutup apa yang telah dihilangkan oleh Adam.-Ul 19:21.

${ }^{2}$ William Dyrness, Tema-Tema Dalam Teologi Perjanjian Lama, (Malang: Penerbit Gandum Mas, 1992), cet. kedua, hlm. 133. 
Paulus menekankan bahwa Kematian Yesus di kayu salib menyatakan kebenaran dan keadilan Allah. ${ }^{3}$ Penulis surat Ibrani menyatakan dengan sangat jelas adalah korban yang satu-satunya yang perlu membebaskan kita dari dosa, dan korban Tuhan Yesus bersifat kekal atau selamanya. Hal ini membuktikan bahwa Allah tidak mau manusia binasa. Oleh karena itu Kristus telah mati sebagai korban yang dipersembahkan oleh Allah untuk memenuhi tuntutan keadilan Allah yang dinyatakan untuk penyelesaian dosa manusia. Dengan demikian keberadaan manusia diperdamaikan kembali dengan Allah dan manusia melalui pengorbanan Tuhan Yesus kembali memperoleh keberadaan manusia sebelum manusia berdosa. Korban identik dengan persembahan yang dimana ada tujuan yang hendak dicapai. Korban dalam kitab Imamat membawa kita pada pengertian tentang penebusan Kristus bagi dosa manusia. Roma 5:6-10

"Karena waktu kita masih lemah, Kristus telah mati untuk kita orang-orang durhaka pada waktu yang ditentukan oleh Allah. Sebab tidak mudah seorang mau mati untuk orang yang benar--tetapi mungkin untuk orang yang baik ada orang yang berani mati--. Akan tetapi Allah menunjukkan kasih-Nya kepada kita, oleh karena Kristus telah mati untuk kita, ketika kita masih berdosa. Lebih-lebih, karena kita sekarang telah dibenarkan oleh darah-Nya, kita pasti akan diselamatkan dari murka Allah. Sebab jikalau kita, ketika masih seteru, diperdamaikan dengan Allah oleh kematian Anak-Nya, lebihlebih kita, yang sekarang telah diperdamaikan, pasti akan diselamatkan oleh hidup-Nya!"

Yesus Kristus mati untuk kita, ketika kita masih berdosa dan masih merupakan musuh Allah. Dengan kematian-Nya, Ia memperdamaikan kita dengan Allah, karena kematian-Nya telah membebaskan kita dari semua dosa kita dan mengubah kita-ketika kita percaya-dari orang berdosa menjadi orang benar. Sebagaimana dikatakan juga dalam 1 Petrus 3:18.

${ }^{3}$ Robert Peterson, Tafsiran Kitab Imamat (Jakarta: BPK Gunung Mulia, 1994), hal. 79. 


\section{c. Menyucikan}

Darah binatang tidak memadai untuk menebus dosa manusia, hanya bersifat sementara. Dosa terhadap Allah yang suci dan kekal menuntut korban yang suci dan kekal juga. "Tetapi justru oleh korban-korban itu setiap tahun orang diperingatkan akan adanya dosa. Sebab tidak mungkin darah lembu jantan atau darah domba jantan menghapuskan dosa"(Ibr 10:3-4). Sementara darah lembu jantan dan domba jantan ini lebih dimaksudkan sebagai pengingat akan dosa, "darah Kristus yang mahal, yaitu darah anak domba yang tak bernoda dan tak bercacat" (1 Pet 1:19), dibayarkan sebagai penebusan dosa manusia, sehingga kita tidak lagi membutuhkan korban penebusan dosa. Menjelang kematian-Nya, Yesus berkata, "Sudah selesai." Dia benar-benar bermaksud menyatakan itu - bahwa semua karya penebusan telah selesai dikerjakan, "telah mendapat kelepasan yang kekal” (Ibrani 9:12).

Darah Kristus tidak hanya menebus orang pilihan dari belenggu dosa dan penghukuman kekal, tetapi juga untuk "menyucikan hati nuraninya dari perbuatan-perbuatan yang sia-sia, supaya dia dapat beribadah kepada Allah yang hidup" (Ibrani 9:14). Ini berarti kita tidak hanya dibebaskan dari upacara korban persembahan yang sia-sia dan tidak bisa menyelamatkan, tetapi kita juga dibebaskan dari ketergantungan atas upaya dan usaha kita yang tidak bernilai dan berarti untuk menyenangkan hati Allah. Karena darah Kristus telah menebus kita, maka kita sekarang menjadi ciptaan baru di dalam Kristus (2 Kor 5:17). Karena darah-Nya, kita dibebaskan dari belenggu dosa sehingga kita bisa melayani Allah yang hidup; untuk memuliakan-Nya dan hidup dalam anugerah-Nya untuk selama-lamanya. Realitas darah Kristus sebagai sarana penebusan dosa terkait erat dengan Hukum Musa. Setahun sekali, para imam melakukan upacara persembahan kurban darah binatang di mezbah Bait Allah untuk penghapusan dosa manusia. " Dan hampir segala sesuatu disucikan menurut hukum Taurat dengan darah, dan tanpa penumpahan darah tidak ada pengampunan" (Ibrani 9:22). Penumpahan darah binatang ini terbatas keefektifannya, sehingga harus diulang berkali-kali. Upacara ini sebenarnya menjadi 
bayang-bayang dari persembahan "satu kali untuk selama-lamanya" yang dilakukan Yesus di atas kayu salib (Ibrani 7:27). Sekali korban ini sudah dipersembahkan, maka tidak lagi diperlukan darah lembu dan domba. Kuasa Darah Tuhan Yesus sangat luar biasa. DarahNya membersihkan kita dari segala dosa dan kejahatan kita. Yesaya 1: 18 berkata : "Sekalipun dosamu merah seperti kirmizi, akan menjadi putih seperti salju; sekalipun berwarna merah seperti kain kesumba, akan menjadi putih seperti bulu domba." Oleh kuasa darahNya kita beroleh keselamatan dari maut kepada hidup yang kekal. Kuasa Darah Tuhan Yesus sangat luar biasa. DarahNya membersihkan kita dari segala dosa dan kejahatan kita. Yesaya 1: 18 berkata : "Sekalipun dosamu merah seperti kirmizi, akan menjadi putih seperti salju; sekalipun berwarna merah seperti kain kesumba, akan menjadi putih seperti bulu domba." Oleh kuasa darahNya kita beroleh keselamatan dari maut kepada hidup yang kekal. 


\section{DAFTAR PUSTAKA}

Ghazali, Adang Muchtar. Antropologi Agama. Bandung: Alfabeta, 2011

Robert Peterson, Tafsiran Kitab Imamat, Jakarta: BPK Gunung Mulia, 1994

Lasor, W.S dkk, Pengantar Perjanjian Lama 1, Jakarta: BPK.Gunung Mulia, 2001

William Dyrness, Tema-Tema Dalam Teologi Perjanjian Lama, Malang: Penerbit

Gandum Mas, 1992

Wikarman, I Nyoman Singgin. Caru: Palemahan dan Sasih. Surabaya: Paramita, 1998. 